\title{
Long neglected diversity in the Accursed Mountains of northern Albania: Cerastium hekuravense is genetically and morphologically divergent from $C$. dinaricum
}

\author{
Danka Caković $^{1} \cdot$ Danijela Stešević $^{1} \cdot$ Peter Schönswetter $^{2} \cdot$ Božo Frajman $^{2}$ (I)
}

Received: 25 April 2017 / Accepted: 17 July 2017 / Published online: 30 August 2017

(C) The Author(s) 2017. This article is an open access publication

\begin{abstract}
The Balkan Peninsula is a hotspot of European biotic diversity. One of its biogeographically most peculiar but poorly explored regions are the Albanian Alps (Alpet Shqiptare/Prokletije/Accursed Mountains) on the border between Albania, Kosovo and Montenegro, characterised by a high number of endemic species. A poorly known taxon from the Albanian Alps is Cerastium hekuravense, which was described from Mt. Maja Hekurave (Albania) in 1921, but later usually merged with $C$. dinaricum, a widespread endemic of the Dinaric Mountains, or connected with the arctic-alpine $C$. alpinum. Here, we used amplified fragment length polymorphisms to explore the phylogenetic position of $C$. hekuravense and particularly its relationship to C. dinaricum. Our data show that both species are genetically well differentiated, but their relation to other taxa remains unclear-they are either closely related to Alpine species of $C$. ser. Latifolia or to species co-occurring on the Balkan Peninsula, such as $C$. banaticum and $C$. decalvans. In addition, multivariate morphometric analyses show that C. dinaricum and $C$. hekuravense are morphologically well differentiated. Also their relative genome sizes, estimated
\end{abstract}

Handling editor: Christoph Oberprieler.

Electronic supplementary material The online version of this article (doi:10.1007/s00606-017-1448-1) contains supplementary material, which is available to authorized users.

Božo Frajman

bozo.frajman@uibk.ac.at

1 Department of Biology, Faculty of Natural Sciences and Mathematics, University of Montenegro, G. Washington Street, 81000 Podgorica, Montenegro

2 Institute of Botany, University of Innsbruck, Sternwartestrasse 15, 6020 Innsbruck, Austria using flow cytometry, differ. We propose a taxonomic treatment with lectotype designation for both taxa and provide descriptions and an identification key. Last but not least, these cold-adapted species mostly growing on northerly exposed humid screes are highly threatened due to the global warming and should be ranked endangered according to IUCN criteria. Cerastium hekuravense known only from three localities is likely one of the most endangered mountain plant species of the Balkan Peninsula.

Keywords AFLP · Albanian Alps · Balkan Peninsula · Endemism $\cdot$ Genome size $\cdot$ IUCN $\cdot$ Taxonomy

\section{Introduction}

The Balkan Peninsula is a centre of plant species diversity and endemism; it is the floristically richest area in Europe harbouring about 6500 species, of which more than onethird (c. 2600-2700) are endemic and about 400 are considered to be local endemics (Horvat et al. 1974; Kryštufek and Reed 2004; Stevanović et al. 2007). These numbers are likely an underestimate, as only for Greece, including Crete and the islands, 5752 species, of which 1278 are endemic to this country, have been reported (Dimopoulos et al. 2013). In the western Balkan Peninsula, especially the high mountain system of the Dinarides (Dinaric Mountains) is highly diverse (Horvat et al. 1974; Redžić 2011). It spans from Slovenia in the North to northern Albania in the South, where the highest peak, Maja Jezercë (2694 m), is situated. This southernmost part of the Dinarides, which is known as Albanian Alps (Alpet Shqiptare/Bjeshkët e Namuna in Albanian) or Accursed Mountains (Prokletije in the southern Slavic languages), includes ca. 40 peaks over $2000 \mathrm{~m}$ and 17 peaks over 2500 m (Rakaj 2009). 
Roughly 20 plant species are endemic to the Albanian Alps in its broader definition, i.e. including Komovi and Visitor (Rakaj 2009 and references below). Several of them bear the specific epithet "bertisceus" (derived from the Ptolemean "Mons Bertiscus" for the Albanian Alps), pointing to their origin, e.g. Crepis bertiscea Jáv., Draba bertiscea D.Lakušić \& Stevan., Onobrychis bertiscea Širj. \& Rech.f. and Valeriana bertiscea Pančić. In the last decade, two new species endemic to this mountain range have been described, i.e. Androsace komovensis Schönsw. \& Schneew. (Schönswetter and Schneeweiss 2009; Frajman et al. 2014) and Heliosperma oliverae Niketić \& Stevan. (Niketić and Stevanović 2007). In addition, several endemics, including Edraianthus pilosulus (Beck) Surina \& Lakušić (Surina et al. 2009), Heliosperma macranthum Pančić (Frajman and Oxelman 2007; Frajman et al. 2009; see also Frajman et al. 2014) and Wulfenia baldaccii Degen (Surina et al. 2014) have been analysed phylogenetically, confirming their independent status. In contrast, Campanula latifolioides F.K.Mey., recently described by Meyer (2011), is likely a synonym of Asyneuma pichleri (Vis.) Lakušić \& Conti (Pils 2016).

One of the poorly know taxa from the Albanian Alps is Cerastium hekuravense Jáv., which was described by Jávorka (1921) based on a specimen collected on Mt. Maja Hekurave in Albania. Despite the fact that Jávorka compared this species with representatives of $C$. ser. Latifolia Borza (C. carinthiacum Vest, C. subtriflorum Dalla Torre \& Sarnth., C. latifolium L.), it was later commonly included in C. alpinum L. (Jalas 1964; Jalas and Suominen 1983; Jalas 1993; Euro + Med 2006). However, Merxmüller and Strid (1977) suggested that the species does not belong to the C. alpinum group and Niketić (1999) proposed that the glandular indumentum of the leaves is the only difference from C. dinaricum Beck \& Szyszył., an endemic species of the Dinaric Mountains included in C. ser. Latifolia. Moreover, the $C$. alpinum group only includes high polyploid species, from octo- to dodecaploids, whereas the species of $C$. ser. Latifolia, including $C$. dinaricum, are tetraploids (Brysting et al. 2011; Niketić et al. 2013). Niketić (1999) treated $C$. hekuravense as $C$. dinaricum var. hekuravense (Jáv.) Niketić and later (Niketić 2007) as C. dinaricum f. hekuravense (Jáv.) Niketić, which he suggested to occur scattered throughout the distribution range of $C$. dinaricum. However, a detailed study of $C$. dinaricum showed no phylogenetic differentiation between glandular and glabrous plants (Kutnjak et al. 2014). Yet, Kutnjak et al. (2014) did neither include the population from the locus classicus of $C$. hekuravense, Maja Hekurave, nor the only known Albanian population of C. dinaricum from Maja Kakisë east of Abat (Hayek 1924). For the sake of simplicity, we refer to the two focal taxa on the species level and their entirety is denoted as $C$. dinaricum s.1.
Here, we used amplified fragment length polymorphisms (AFLPs), relative genome size (RGS) measurements and morphometric analyses to elucidate the relationship between $C$. hekuravense from the Albanian Alps and the more widespread $C$. dinaricum. Specifically, we address the following questions: (1) Is $C$. hekuravense from the locus classicus (type locality) genetically differentiated from $C$. dinaricum? (2) If so, do the other known and recently discovered populations from the Albanian Alps cluster with $C$. dinaricum or with $C$. hekuravense? (3) Do eventually detected genetic groups differ in RGS and are they also morphologically differentiated? (4) Based on our results, we provide a taxonomic treatment of both taxa and evaluate their conservation status following the IUCN criteria.

\section{Materials and methods}

\section{Plant material}

Molecular analyses are based on silica gel-dried leaf material. We included four populations of Cerastium dinaricum previously analysed by Kutnjak et al. (2014), including the population from the type locality, and additionally sampled four populations from Albania tentatively ascribed to $C$. dinaricum s.l., including the population from the type locality of $C$. hekuravense (Table 1, Fig. 1). Additionally, we included all other species (Online Resource 1) classified within the $C$. latifolium aggregate (Niketić 2007)—C. carinthiacum (two populations), C. latifolium (two populations) and $C$. uniflorum Clairv. (one population), as well as the species distributed on the Balkan Peninsula, which include tetraploid populations (Niketić et al. 2013), i.e. C. banaticum (Rochel) Steud. (six populations), C. decalvans Schloss. \& Vuk. (three populations), C. eriophorum Kit. (four populations) and $C$. grandiflorum Waldst. \& Kit. (two populations), to infer the phylogenetic position of $C$. dinaricum and C. hekuravense.

\section{AFLP analyses}

Extraction of total genomic DNA was performed following the modified CTAB-protocol of Tel-Zur et al. (1999). AFLP fingerprinting was conducted as described by Kutnjak et al. (2014). Two blanks (DNA replaced by water) were included to test for contamination, and four samples were used as replicates between the two PCR batches to test the reproducibility. Numbers of sampled individuals per population are provided in Table 1.

Electropherograms were analysed with Peak Scanner version 1.0 (Applied Biosystems) using default peak detection parameters except employing light peak smoothing. The minimum fluorescent threshold was set to 100 
Table 1 Studied populations of Cerastium dinaricum and C. hekuravense

\begin{tabular}{|c|c|c|c|c|c|c|c|c|c|}
\hline ID & Lab ID & Taxon & Sampling locality & $\begin{array}{l}\text { Altitude } \\
\text { (m a.s.1.) }\end{array}$ & $\begin{array}{l}\text { Longitude (E)/Lati- } \\
\text { tude }(\mathrm{N})\end{array}$ & $\begin{array}{l}\text { Collectors (col- } \\
\text { lection number) }\end{array}$ & Voucher & $\mathrm{N}_{\mathrm{AFLP}}$ & RGS \\
\hline 1 & C101 & C. dinaricum & $\begin{array}{l}\text { HR: Velebit, Mt. } \\
\text { Vaganski vrh }\end{array}$ & 1690 & $15.50419 / 44.365471$ & $S B$ and $I R$ & $\begin{array}{l}\text { ZA-H- } \\
\text { 010-Cdin }\end{array}$ & 3 & $0.306( \pm 0.002)$ \\
\hline 2 & C018 & C. dinaricum & $\begin{array}{l}\text { BH: Prenj, Vjetrana } \\
\text { brda ridge }\end{array}$ & 1864 & $17.881667 / 43.54861$ & $\begin{array}{l}P S, B F \text { and } D K \\
12864\end{array}$ & IB & 4 & $0.320( \pm 0.005)$ \\
\hline 3 & $\mathrm{C} 020$ & C. dinaricum & $\begin{array}{l}\text { ME: Durmitor, valley } \\
\text { of Škrčko jezero }\end{array}$ & 1883 & $19.03 / 43.12833$ & $\begin{array}{l}P S, B F \text { and } D K \\
12909\end{array}$ & IB & 5 & $0.323( \pm 0.004)$ \\
\hline 4 & $\mathrm{C} 022$ & C. dinaricum & $\begin{array}{l}\text { ME: Komovi, summit } \\
\text { of Mt. Kom Kučki }\end{array}$ & 2394 & $19.6425 / 42.678611$ & $\begin{array}{l}P S, B F \text { and } D K \\
12931\end{array}$ & IB & 3 & $0.323( \pm 0.003)$ \\
\hline 5 & C466 & C. dinaricum & $\begin{array}{l}\text { AL: Alpet Shqiptare/ } \\
\text { Prokletije, summit } \\
\text { of Maja Jezercë }\end{array}$ & 2638 & $19.811 / 42.443056$ & $\begin{array}{l}P S, B F \text { and } M F \\
13780\end{array}$ & IB & 5 & $0.318( \pm 0.002)$ \\
\hline 6 & C499 & C. hekuravense & $\begin{array}{l}\text { AL: Alpet Shqiptare/ } \\
\text { Prokletije, Buni } \\
\text { Jezercë }\end{array}$ & 1850 & $19.81167 / 42.45944$ & $\begin{array}{c}D C \text { and } D S \\
14399\end{array}$ & IB & 7 & $0.371( \pm 0.004)$ \\
\hline 7 & $\mathrm{C} 024$ & C. hekuravense & $\begin{array}{l}\text { AL: Alpet Shqiptare/ } \\
\text { Prokletije, Maja } \\
\text { Hekurave }\end{array}$ & 2019 & $19.94694 / 42.3944$ & $\begin{array}{l}P S, B F \text { and } D K \\
13000\end{array}$ & IB & 4 & $0.374( \pm 0.003)$ \\
\hline 8 & C477 & C. hekuravense & $\begin{array}{l}\text { AL: Alpet Shqiptare/ } \\
\text { Prokletije, Maja } \\
\text { Kakisë }\end{array}$ & 1935 & $19.82388 / 42.35944$ & $\begin{array}{l}P S \text { and } B F \\
14009\end{array}$ & IB & 5 & $0.361( \pm 0.003)$ \\
\hline
\end{tabular}

$I D$ population identifier used throughout the paper. $A L$ Albania, $B H$ Bosnia and Hercegovina, $H R$ Croatia, $M E$ Montenegro. $N_{A F L P}$ number of individuals investigated with amplified fragment length polymorphism. $R G S$ relative genome size (mean \pm standard deviation). Collectors: $B F$ B. Frajman, $D C$ D. Caković, $D K$ D. Kutnjak, $D S$ D. Stešević, $I R$ I. Rešetnik, $M F$ M. Falch, $P S$ P. Schönswetter, SB S. Bogdanović

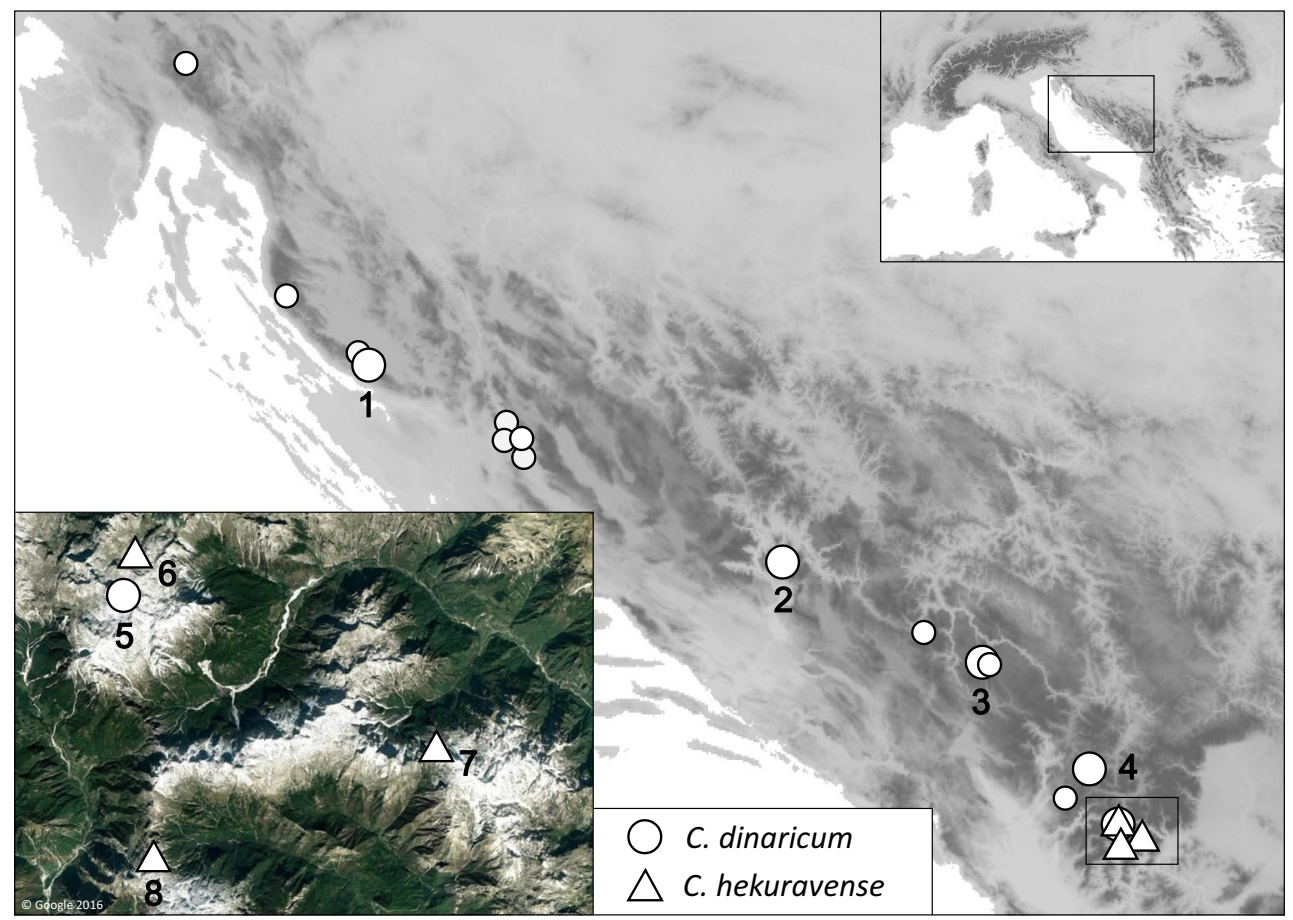

Fig. 1 Sampled populations of Cerastium dinaricum and C. hekuravense. Population numbers correspond to Table 1. Smaller symbols indicate non-sampled localities of $C$. dinaricum, where the species certainly occurs (see Kutnjak et al. 2014). The inset in the upper right corner shows the position of the sampling area in Europe; the rectangle in the main part of the figure indicates the position of the Albanian Alps magnified in the inset in the lower left corner 
relative fluorescence units. Automated binning and scoring of the AFLP fragments were performed using RawGeno 2.0-1 (Arrigo et al. 2009) for R 2.15.2 (R Development Core Team 2012) with the following settings: scoring range $=150-500 \mathrm{bp}$, minimum intensity $=100$ relative fluorescence units (rfu), minimum bin width $=1 \mathrm{bp}$ and maximum bin width $=1.5 \mathrm{bp}$. Fragments with a reproducibility lower than $85 \%$ based on sample-replicate comparisons were eliminated. Fragments present/absent in only one individual were excluded.

A Neighbour-joining (NJ) analysis based on Nei-Li genetic distances (Nei and Li 1979) was conducted and bootstrapped (2000 pseudo-replicates) with TREECON v.1.3b (van de Peer and De Wachter 1997). The tree was rooted with $C$. grandiflorum based on an ITS phylogeny (Frajman B., unpublished). Due to the simple structure in the data, no further analyses were conducted.

\section{Genome size measurements}

Flow cytometry (FCM) of 40,6-diamidino-2-phenylindole (DAPI)-stained nuclei was used to estimate relative genome size (RGS) of four newly sampled populations (all populations from Albania) as described by Kutnjak et al. (2014). The RGS was estimated for three to ten individuals per population.

Absolute genome size (AGS) was determined using FCM of propidium iodide (PI)-stained nuclei of two samples of $C$. dinaricum and one sample of $C$. hekuravense (Table 1) as described by Frajman et al. (2015), with the exception that Pisum sativum cv. Kleine Rheinländerin $(2 \mathrm{C}=8.84 \mathrm{pg}$; Greilhuber and Ebert 1994) was used as reference standard.

\section{Morphometric analyses}

Material for morphometric analyses included vouchers of all molecularly investigated populations of $C$. dinaricum s.l. (Table 1), supplemented with herbarium vouchers stored in the herbarium of the University of Innsbruck, IB (Frajman and Schönswetter 14631, 14632, 14633), totalling 54 individuals. Forty characters were measured or counted and 15 ratios were calculated (Table 2). Leaf characters were measured on the uppermost and one welldeveloped mid-stem leaf; the apex angle was measured only on the mid-stem leaf. Trichome characters were measured on the upper surface and the margin of a midstem leaf, as well as on the internode below the investigated leaf. Certain characters were missing in a few individuals, e.g. petals or fully developed fruits, and were thus replaced with mean values calculated for the other studied populations of the same species. Petal, sepal, bract, leaf and fruit characters were measured on images taken with a camera mounted on a Zeiss SteREO Discovery. V12 stereo microscope at $8 \times$ magnification. Characters of trichomes were measured on magnified images taken with an Olympus UC 30 wide zoom camera mounted on an Olympus SZX9 stereo microscope with $20 \times$ magnification.

We tested correlation among metric characters employing Pearson or Spearman correlation coefficients dependent on character distribution. After standardization to zero mean and one unit variance, principal component analysis (PCA) was performed. As Tukey HSD Post hoc test showed no discriminatory power ( $p$ values between 0.33 and 0.98$)$ for twelve characters $(1,2,11,12,18,19,24$, $30,48,49,53$ and 55) and three ratios (33, 36 and 39) we excluded them from the canonical discriminant analysis (CDA), which was applied to inspect the separation between $C$. dinaricum and $C$. hekuravense and the relative importance of characters as discriminators between them. Statistical analyses were performed using the package Statistica 5.1 (StatSoft 1996). Values presented in the species descriptions and in the identification key correspond to the 10 and $90 \%$ quantiles, supplemented by extreme values in parentheses.

\section{Results}

\section{AFLP analyses}

We scored 335 AFLP fragments for 96 individuals; 42 bands found in only one individual were excluded. For the 36 individuals of Cerastium dinaricum s.l. we scored 196 fragments, of which 43 found in only one individual were excluded from further analyses.

The neighbour-joining tree of AFLP profiles (Fig. 2) resulted in a strongly supported cluster (bootstrap support, BS 100) containing all species except $C$. grandiflorum, which was used for rooting. Within this cluster, three moderately to well-supported groups were resolved; the relationships among them were unresolved. One group included all accessions of $C$. dinaricum s.l. with strong support (BS 87), falling in two strongly supported clusters (both with BS 100). One of them contained accessions of $C$. dinaricum studied by Kutnjak et al. (2014) including the population from the locus classicus, as well as one newly sampled population from the summit of Maja Jezercë in Albania. The other cluster contained the population from Maja Hekurave, locus classicus of $C$. hekuravense, as well as the populations from Buni Jezercë and Maja Kakisë. The two remaining major groups contained species of $C$. ser. Latifolia from the Alps (C. carinthiacum, C. latifolium, C. uniflorum; BS 91) and Balkan accessions (BS 67) of species belonging to $C$. ser. Alpina (C. decalvans and C. eriophorum) and to C. ser. Cerastium (C. banaticum). 
Table 2 Morphological characters studied

\begin{tabular}{|c|c|c|}
\hline Char. No & Character & Abbreviations \\
\hline 1 & Petal length, mm & PL \\
\hline 2 & Petal width, mm & PW \\
\hline 3 & Ratio of petal length and petal width & PL/PW \\
\hline 4 & Distance from petal basis to incision, $\mathrm{mm}$ & LPBI \\
\hline 5 & Ratio of distance from petal basis to incision and petal length & $\mathrm{LPBI} / \mathrm{PL}$ \\
\hline 6 & Sepal length, mm & CLL \\
\hline 7 & Sepal width, mm & CLW \\
\hline 8 & Ratio of sepal length and width & CLL/CLW \\
\hline 9 & Distance from basis to widest part of sepal, $\mathrm{mm}$ & CLLMW \\
\hline 10 & Ratio of distance from basis to widest part of sepal and sepal length & CLLMW/CLL \\
\hline 11 & Width of hyaline margin of sepal, mm & CLHM \\
\hline 12 & Bract length, mm & $\mathrm{BL}$ \\
\hline 13 & Bract width, mm & BW \\
\hline 14 & Ratio of bract length and width & $\mathrm{BL} / \mathrm{BW}$ \\
\hline 15 & Distance from basis to widest part of bract, $\mathrm{mm}$ & BLLMW \\
\hline 16 & Ratio of distance from basis to widest part of bract and bract length & BLLMW/BLL \\
\hline 17 & Width of the hyaline margin of bracts, $\mathrm{mm}$ & BHM \\
\hline 18 & Length of uppermost leaves, $\mathrm{mm}$ & ULL \\
\hline 19 & Width of uppermost leaves, mm & ULW \\
\hline 20 & Ratio of length and width of uppermost leaves & ULL/ULW \\
\hline 21 & Distance from basis to widest part of uppermost leaves, $\mathrm{mm}$ & ULLMW \\
\hline 22 & Ratio of distance from basis to widest part of uppermost leaves and their length & ULLMW/ULL \\
\hline 23 & Length of mid-stem leaves, mm & MLL \\
\hline 24 & Width of mid-stem leaves, mm & MLW \\
\hline 25 & Ratio of length and width of mid-stem leaves & MLL/MLW \\
\hline 26 & Distance from basis to widest part of mid-stem leaves, $\mathrm{mm}$ & MLLMW \\
\hline 27 & Ratio of distance from basis to widest part of mid-stem leaves and their length & MLLMW/MLL \\
\hline 28 & Angle of the apex of mid-stem leaves, degree & ASL \\
\hline 29 & Capsule length, mm & CL \\
\hline 30 & Capsule width, mm & $\mathrm{CW}$ \\
\hline 31 & Ratio of capsule length and width & $\mathrm{CL} / \mathrm{CW}$ \\
\hline 32 & Distance from basis to widest part of capsule, $\mathrm{mm}$ & CLMW \\
\hline 33 & Ratio of distance from basis to widest part of the capsule and capsule length & CLMW/CL \\
\hline 34 & Capsule teeth length, $\mathrm{mm}$ & CTL \\
\hline 35 & Capsule teeth width, mm & CTW \\
\hline 36 & Ratio of length and width of capsule teeth & CTL/CTW \\
\hline 37 & Seed length, mm & SL \\
\hline 38 & Seed width, mm & SW \\
\hline 39 & Ratio of seed length and width & SL/SW \\
\hline 40 & Stem length, mm & $\mathrm{SH}$ \\
\hline 41 & Number of internodes & IN \\
\hline 42 & Ratio of stem length and number of internodes & $\mathrm{SH} / \mathrm{IN}$ \\
\hline 43 & Length of internode adjacent to mid-stem leaf pair, mm & IL \\
\hline 44 & Number of flowers per stem & FN \\
\hline 45 & Length of peduncle of terminal flower, $\mathrm{mm}$ & PTFL \\
\hline 46 & Length of inflorescence (from the terminal flower to the top), $\mathrm{mm}$ & IFL \\
\hline 47 & Number of internodes in the longest inflorescence branch & IFLIN \\
\hline 48 & $\begin{array}{l}\text { Number of glandular hairs per } \mathrm{mm}^{2} \text { on the upper epidermis of mid-stem leaves, calculated as the average of } \\
\text { two squares with } 1 \mathrm{~mm}^{2} \text { each }\end{array}$ & GHLS \\
\hline
\end{tabular}


Table 2 (continued)

\begin{tabular}{|c|c|c|}
\hline Char. No & Character & Abbreviations \\
\hline 49 & $\begin{array}{l}\text { Number of eglandular hairs per } \mathrm{mm}^{2} \text { on the upper epidermis of mid-stem leaves, calculated as the average of } \\
\text { two squares with } 1 \mathrm{~mm}^{2} \text { each }\end{array}$ & EHLS \\
\hline 50 & Number of glandular hairs on the margin of mid-stem leaves along $1 \mathrm{~mm}$ just below the tip of the leaf & GHLM \\
\hline 51 & Number of eglandular hairs on the margin of mid-stem leaves along $1 \mathrm{~mm}$ just below the tip of the leaf & EHLM \\
\hline 52 & Length of the longest trichome on the margin of mid-stem leaves along $1 \mathrm{~mm}$ just below the tip of the leaf & TLM \\
\hline 53 & Number of glandular hairs on the stem along $1 \mathrm{~mm}$ just below a mid-stem leaf pair & GHS \\
\hline 54 & Number of eglandular hairs on the stem along $1 \mathrm{~mm}$ just below a mid-stem leaf pair & EHS \\
\hline 55 & Length of the longest trichome on the stem along $1 \mathrm{~mm}$ just below a mid-stem leaf pair & TLS \\
\hline
\end{tabular}

\section{Genome size of Cerastium dinaricum and $C$. hekuravense}

Average RGS of $C$. hekuravense ranged from 0.361 in population 8 to 0.374 in population 7 and was distinctly different from the mean RGS of $C$. dinaricum, which ranged from 0.301 to 0.327 (Kutnjak et al. 2014); the average RGS of the population 5 from Maja Jezercë was 0.318 and thus within this range (Table 1, Fig. 3). The AGS of C. dinaricum ranged from $2.5674 \mathrm{pg}$ (population 4 from the locus classicus) to $2.5713 \mathrm{pg}$ (population 2), whereas the AGS of C. hekuravense (population 7 from the locus classicus) was $3.0311 \mathrm{pg}$.

\section{Morphological differentiation between Cerastium dinaricum and C. hekuravense}

The measured and counted values for the characters, as well as the calculated ratios, are presented in Online Resource 2. As the correlation coefficients did not exceed 0.9 for any character pair, we included all characters listed in Table 2 in further analyses.

The PCA (first three axes explaining 15.78, 10.98 and $8.06 \%$ of the total variation; Fig. 4a) showed a clear separation between $C$. dinaricum and $C$. hekuravense along the first two axes. The characters contributing most to the separation along the first axis, i.e. those having highest component scores in the coefficient matrix, describe habit $(\mathrm{SH}, \mathrm{SH} / \mathrm{IN}$, IL), shape of the sepals (CLL/CLW), as well as shape of the middle leaves and bracts (MLL/MLW, BL/BW). Leaf, bract and trichome characters (ULLMW, MLLMW, MLLMW/ MLL, BLMW, BLMW/BL, GHLM, EHLM) contributed most to the separation along the second axis. The CDA (Fig. 4b) showed a clear differentiation between the two species with the strongest contribution of the sepal characters (CLL/CLW, CLLMW, CLW, CLLMW/CL). Still, even for characters with high discriminatory power (Tukey HSD post hoc test, $P<0.001$ ) boxplots (Fig. 5) show overlap in character states between both taxa.

\section{Discussion}

Cerastium hekuravense is a distinct species, which is genetically and morphologically clearly differentiated from $C$. dinaricum (Figs. 2, 4, 6, 7). The two species also have different genome sizes (Fig. 3) and even where they occur in relatively close vicinity, such as on the summit of Maja Jezercë (C. dinaricum) and close to Buni Jezercë (C. hekuravense) no traces of gene flow have been detected in the AFLP data. Despite the fact that Niketic $(1999,2007)$ treated $C$. hekuravense as a variety or even as a form of C. dinaricum, which he suggested to be scattered throughout the distribution range of the latter, our data clearly show that $C$. hekuravense is endemic to the Albanian Alps, thus additionally underlining the importance of this mountain range as an endemic-rich area (Rakaj 2009; see also Introduction).

In spite of the peculiarity of its rich flora, Albania is one of the botanically least explored regions of Europe (Markgraf 1932; Frajman et al. 2014). After the last editions of the national flora (Paparisto et al. 1988; Qosja et al. 1992, 1996; Vangjeli et al. 2000) including 3758 taxa (3250 species) of vascular plants, a multitude of species new for Albania have been published (e.g. Barina and Pifkó 2008; Rakaj 2009; Ball 2011; Meyer 2011; Barina et al. 2013; Frajman et al. 2014). Even if $C$. hekuravense was described from the territory of Albania (Jávorka 1921), it was neglected in all recent Albanian floras, where only $C$. dinaricum was listed (Demiri 1983; Paparisto et al. 1988; Vangjeli 2003). In addition to clarifying the status of the known populations from Maja Hekurave and Maja Kakisë (the latter was published as C. dinaricum by Hayek 1924), we discovered an additional population of $C$. hekuravense close to Buni Jezercë (an indication of its occurrence there was kindly provided by M. Niketić; 10.10.2013, personal comm. with B. Frajman) as well as the only known population of $C$. dinaricum in Albania, on the western summit crest of Maja Jezercë.

Spatially explicit modelling of viable habitat for $C$. dinaricum suggested a decrease of about $37 \%$ by the year 2050 and $70 \%$ by the year 2080 due to global warming, and the 


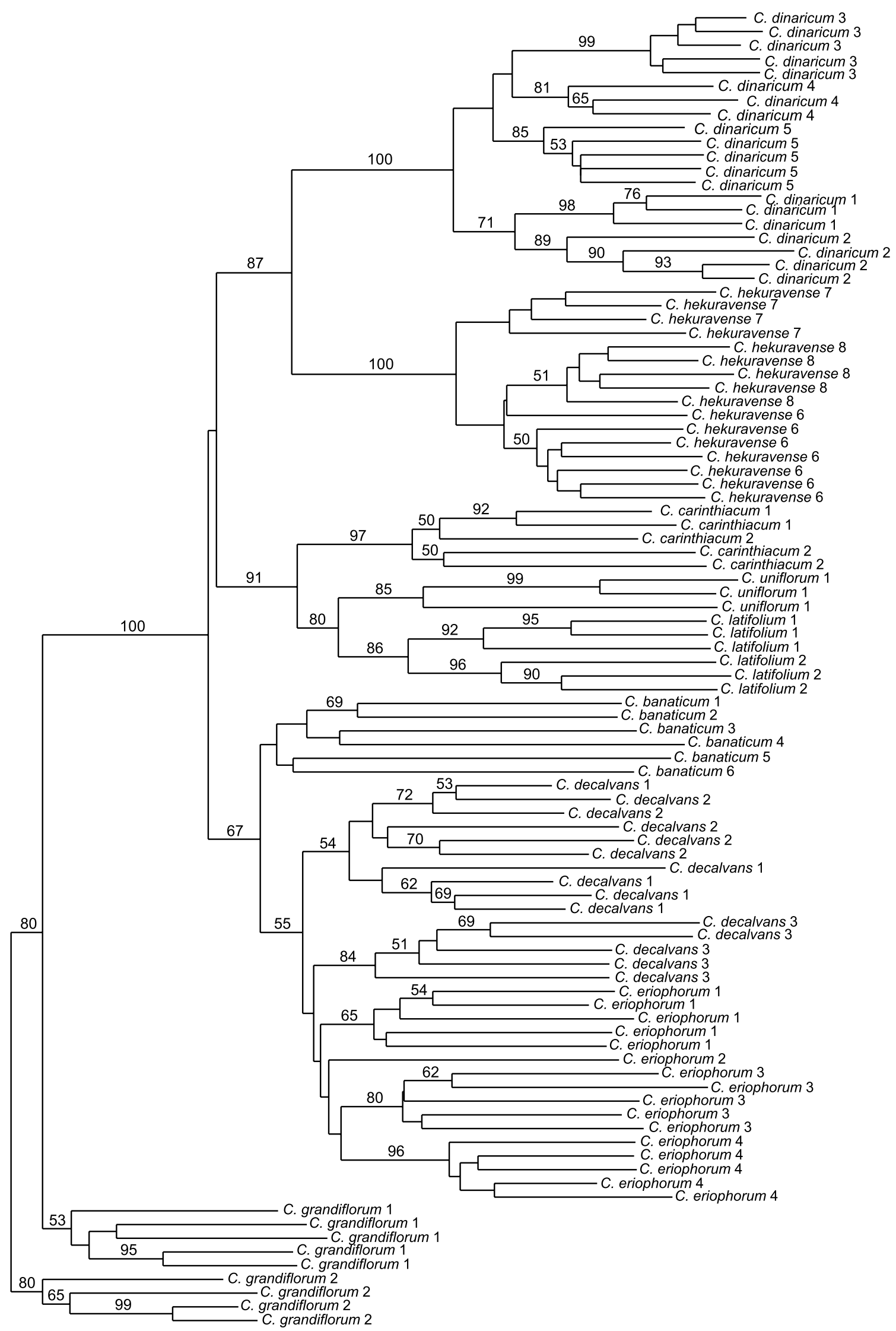

Fig. 2 Neighbour-joining tree derived from AFLP data. Population identifiers correspond to Table 1, Fig. 1 and Online Resource 1 


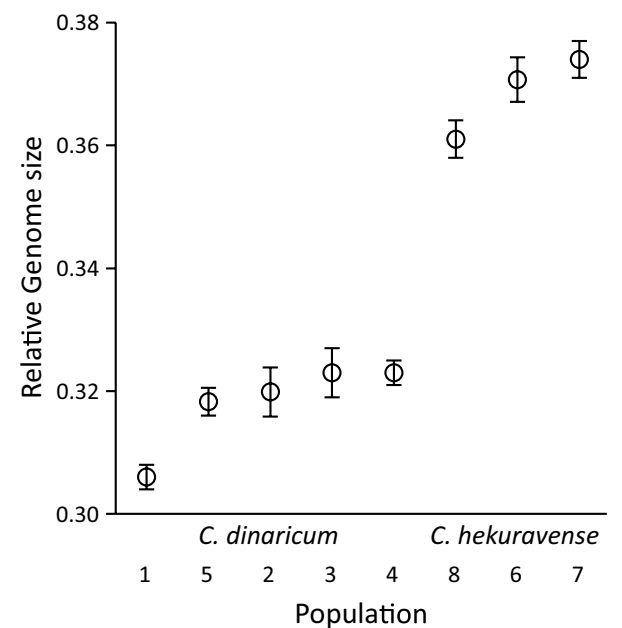

Fig. 3 Relative genome size of Cerastium dinaricum and C. hekuravense as in Table 1. Population numbers correspond to Table 1 and Fig. 1. Circles represent mean values and whiskers the standard deviation

predicted habitat loss could result in range-wide extinction of the species in the very near future (Kutnjak et al. 2014). Thus, following the criterion B2 of the IUCN (2012) for endangered species, the following applies for $C$. dinaricum: (a) area of occupancy is estimated to be less than $500 \mathrm{~km}^{2}$, (b) area of occupancy is severely fragmented and (c) continuing decline in the area, extent and/or quality of habitat has been inferred/projected. Therefore, we deem $C$. dinaricum endangered (EN) according to IUCN (2012).
The situation is similar, but likely more severe for $C$. hekuravense, which has a much narrower distribution and is currently known from only three localities, where it inhabits northerly exposed humid screes with extended snow cover. The ecology of $C$. hekuravense is thus similar to that of C. dinaricum, which, however, thrives also in rock crevices in the summit areas of some mountains (e.g. Kom Kučki in Montenegro and Maja Jezercë in Albania) and thus has a broader ecological niche. Field observations further suggest that $C$. hekuravense prefers more humid and colder screes than C. dinaricum (P. Schönswetter and B. Frajman, personal observations). In all three localities the species was rare, the smallest population being that on Maja Kakisë, where only a few dozen individuals were found. Although we do not have climatic niche modelling data for $C$. hekuravense at hand, extrapolation of the results obtained for C. dinaricum suggests that the species should be treated at least as endangered (EN).

The AFLP data are inconclusive regarding the relationships of $C$. dinaricum and $C$. hekuravense with other tetraploid Cerastium species from the Alps and the Balkans (Niketić et al. 2013). It is clear that they do not belong to the $C$. latifolium aggregate, in which they were included in the past (Jávorka 1921; Niketić 2007). The C. latifolium aggregate thus likely includes only the Alpine broad-leaved species $C$. carinthiacum, $C$. latifolium and C. uniflorum, which form a separate lineage closely related to $C$. dinaricum and $C$. hekuravense. Another group of species closely related to our study taxa are $C$. banaticum, $C$. decalvans and C. eriophorum. They are mostly
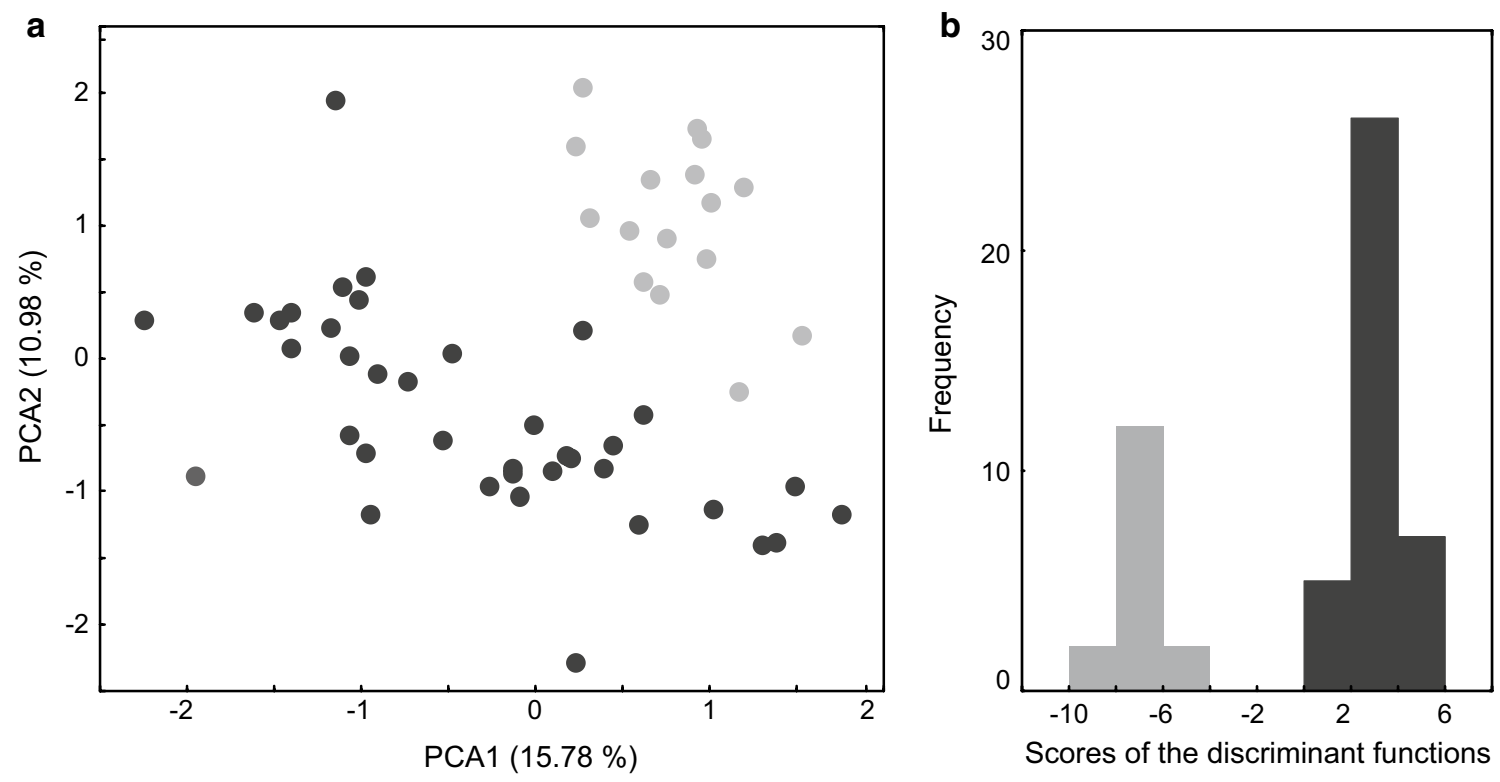

Fig. 4 Morphological differentiation between Cerastium dinaricum (black) and C. hekuravense (grey). a, principal component analysis (PCA) based on 55 morphological characters, b histogram of canonical discriminant analysis (CDA) based on 40 morphological characters 

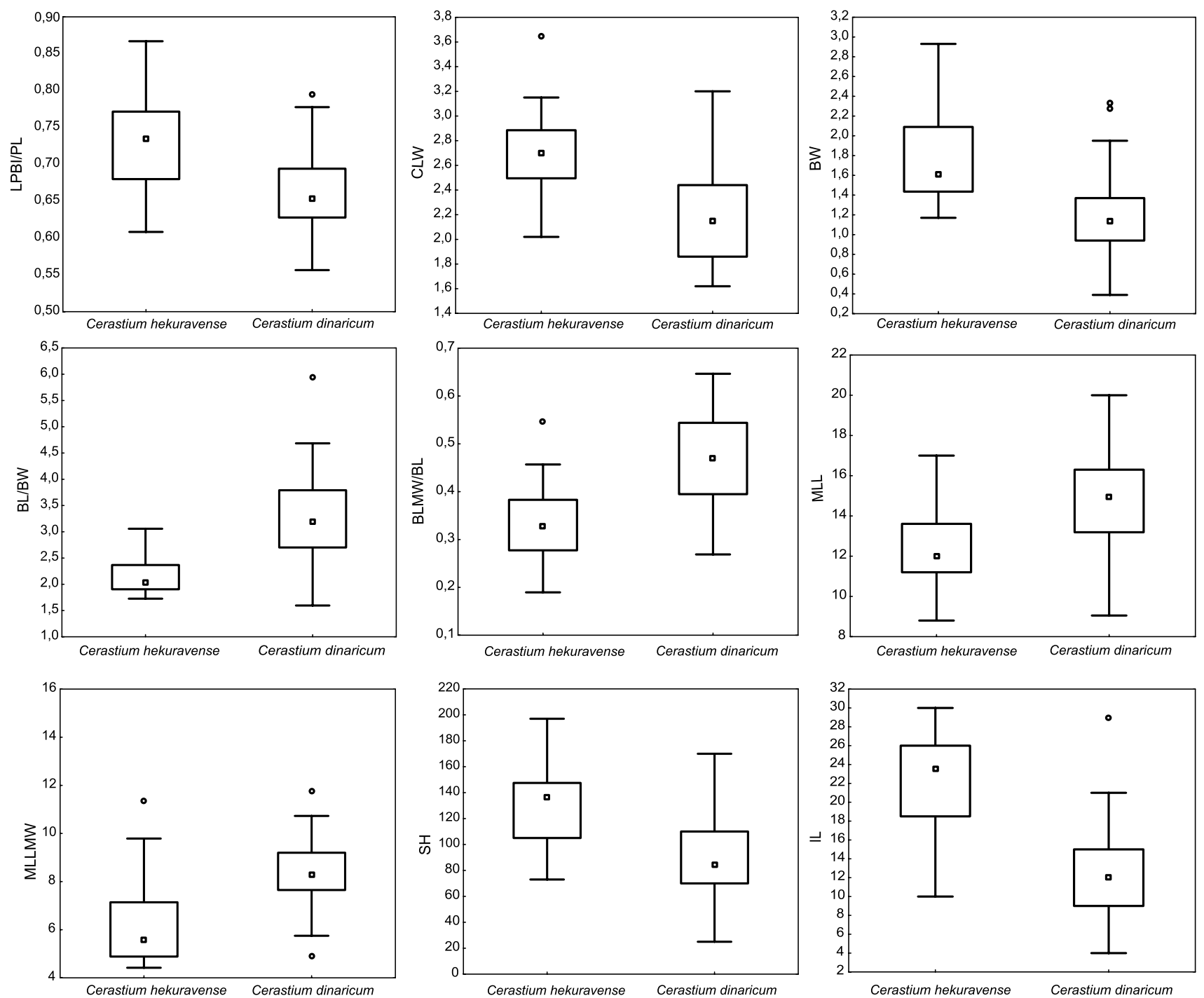

Fig. 5 Boxplot diagrams of morphological characters discriminating between Cerastium dinaricum and C. hekuravense. Boxes define 25 and 75 percentiles; squares indicate medians; whiskers span the 5-95 percentiles and circles indicate outliers. Characters are explained in Table 2

distributed on the Balkan Peninsula and are all characterised by a more or less persistent indumentum. Even if they were classified in two different series by Niketić (2007) - C. banaticum in C. ser. Cerastium, C. decalvans and $C$. eriophorum in $C$. ser. Alpina-they together form a separate lineage, albeit with only moderate bootstrap support $67 \%$ (Fig. 2). Previous phylogenetic studies (Scheen et al. 2004; Brysting et al. 2007, 2011) mostly concentrated on the arctic-alpine members of Cerastium with focus on the origin of high polyploid species; several Balkan taxa, including $C$. dinaricum and $C$. hekuravense, were not sampled. Further phylogenetic studies using nuclear and plastid DNA sequences and broader taxon sampling are thus needed to finally clarify the phylogenetic position of $C$. dinaricum and $C$. hekuravense and to propose a revised infrageneric classification.

\section{Taxonomic treatment}

Cerastium dinaricum G.Beck \& Szysz., Rozpr. Akad. Um. (Mat.-Przyr.) 19: 62. 1889.-—TYPE: “Kom Kucki”, I. Szyszyłowicz, Iter Montenegrinum 1886 (lectotype designated here: PRC 452158!).

$=$ Cerastium dinaricum $\mathrm{f}$. velebiticum Degen \& Lengyel, Magyar Bot. Lapok 6: 126. 1907. 三 Cerastium dinaricum var. velebiticum (Degen \& Lengyel) Graebner \& Corr. in Aschers. \& Graebner, Syn. Mitteleur. Fl. 5(1): 628. 1918.-TYPE: "Croatia. Velebit. In lapidosis alpinis montis Malovan supra Raduč, 1500-1700", 5 Aug 1906, A. de Degen, plantae Hungariae exsiccatae (lectotype designated here: JE 00007505!).

Description: Densely caespitose perennial, with ascending stems (4)7-20(29) $\mathrm{mm}$ long and having (4)5-8(11) 


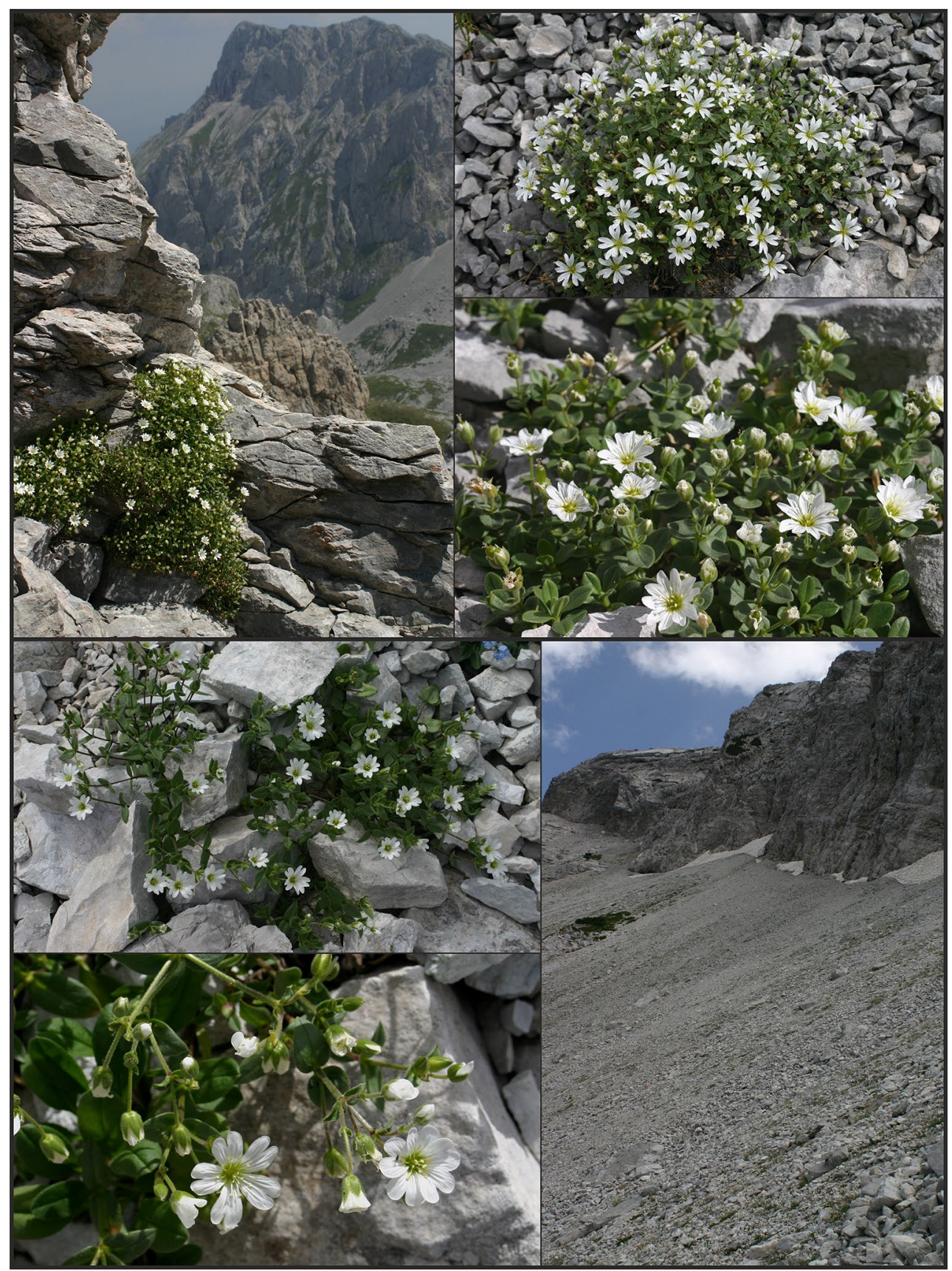

Fig. 6 Cerastium dinaricum (above) and C. hekuravense (below) and their habitats. Photos by B. Frajman and P. Schönswetter

internodes. Leaves sessile, ovate, (9.0)12.5-17.8(20.0) $\mathrm{mm}$ long and (2.1)2.6-5.6(7.2) mm wide, (2.3)2.8-5.2(6.1) times longer than wide, widest at $(0.1) 0.3-0.5(0.6)$ of the length, apex (17.2)26.4-69.6(91.0) ${ }^{\circ}$, upper surface of the leaves glabrous or with indumentum of 2-11(14) glandular and 1-9(10) eglandular hairs per $\mathrm{mm}^{2}$. Bracts (2.2)2.4-5.3(7.8) $\times(0.4) 0.7-1.9(3.0) \mathrm{mm},(1.6) 2.3-4.3(5.9)$ times longer than wide. Flowers (1)2-5(7) per stem. Sepals (2.8)5.0-6.9(7.2) $\mathrm{mm}$ long and (1.6)1.7-2.7(3.2) mm wide, (1.3)2.0-3.6(3.8) times longer than wide, widest at $(0.2) 0.3-0.6(0.9)$ of the length. Petals (6.3)7.0-10.3(10.8) $\mathrm{mm}$ long and (2.7)3.8-6.3(7.0) mm wide, (1.3)1.4-2.2(2.6) times longer than wide, incision (1.6)2.-3.7(3.9) $\mathrm{mm}$ deep, (0.2)0.3-0.4(0.5) of the total petal length. Capsules (7.1) 8.8-11.7(12.6) × (2.1)2.9-4.8(5.5) mm, (1.7)2.0-3.4(3.9) times longer than wide, widest at $(0.2) 0.3-0.5(0.6)$ of the length, (1.1)1.4-2.1(3.5) times longer than the sepals. Seeds (0.1)1.4-1.9(2.0) mm long and (0.5)1.1-1.6(1.8) $\mathrm{mm}$ wide, (0.2)1.0-1.5(1.6) times longer than wide. $2 n=36+1$ (Niketić et al. 2013). 


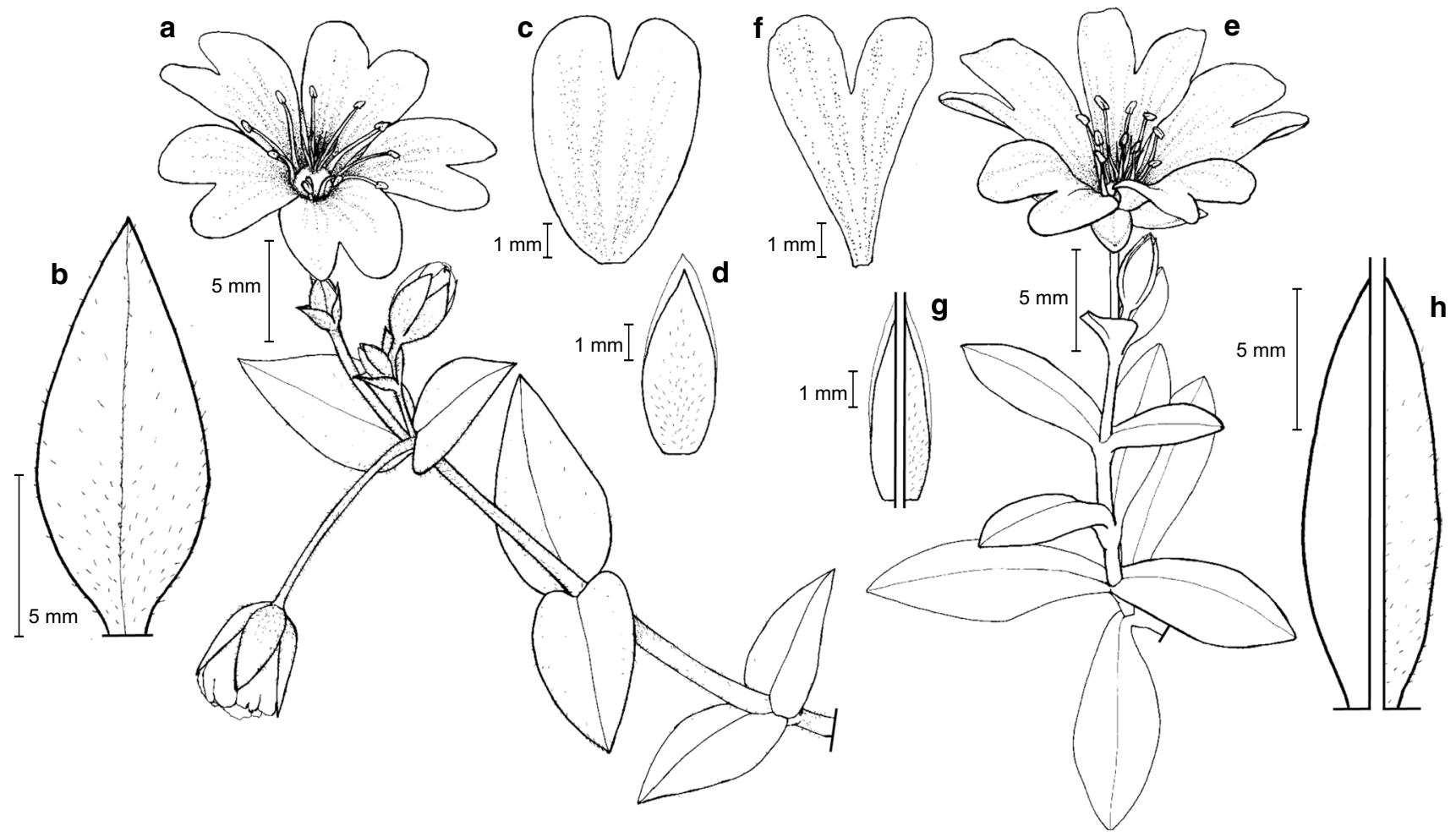

Fig. 7 Iconography of Cerastium hekuravense (a-d) and C. dinaricum (e-h). a, e whole plant; $\mathbf{b}, \mathbf{h}$ stem leaf; $\mathbf{d}, \mathbf{g}$ sepal with indicated hyaline margin; $\mathbf{c}, \mathbf{f}$ petal; in $\mathbf{g}$ and $\mathbf{h}$ the leaf and sepal are divided to indicate that the plant can be glabrous or pubescent. Drawings by M. Magauer

Distribution: Disjunct distribution in the Dinaric Mountains from Mt. Snežnik in Slovenia over Velebit and Dinara in Croatia, Prenj and Volujak in Bosnia and Hercegovina, Durmitor, Komovi and Žijevo in Montenegro to Maja Jezercë in Albania.

Habitat: Usually northerly exposed humid screes and rock crevices mostly in summit areas; the habitat in Slovenia, where it grows on the bottom of a karstic doline with temperature and vegetation inversion, is an exception.

Conservation status: Endangered (EN).

Note: In the protologue also a collection from Malovan (Velebit) is given, but the specimen has not been seen.

Cerastium hekuravense Jáv., Bot. Közl. 19: 18. 1921. 三 Cerastium dinaricum var. hekuravense, (Jáv.) Niketić, Glasn. Prir. muz., Ser. B 49-50: 48. 1999. $\equiv$ Cerastium dinaricum f. hekuravense (Jáv.) Niketić, Endem. predst. roda Cerastium JI Evr.: 52. 2007.—TYPE: "Montes Albaniae borealis versus opp. Djakova extensi: Montes Hekurave. In glareosis calc. sub rupe Maja Drošks supra pag. Dragobija—alt. ca. 1700 m., ad nivem perpetuam", 30 Aug 1918, S. Jávorka, (lectotype designated here: PRM 357775!).
Description: Laxly caespitose perennial, with decumbent stems (10)17-27(30) mm long and having (6)6-8(8) internodes. Leaves sessile, ovate, (8.8)10.1-15.6(17) long and (2.4)2.7-5.9(7.0) mm wide, (1.7)2.0-4.0(5.6) times longer than wide, widest at $(0.1) 0.2-0.4(0.6)$ of the length, apex (23.3)30.4-89.5(97.1) $)^{\circ}$, upper surface of the leaves glabrous or with indumentum of 1-4 glandular and 1-9(10) eglandular hairs per $\mathrm{mm}^{2}$. Bracts (2.4)2.5-5.6(6.4) × (1.2)1.3-2.4(2.9) mm, (1.7)1.8-2.7(3.0) times longer than wide. Flowers 2-5(7) per stem. Sepals (5.3)5.4-7.9(8.0) mm long and (2.0)2.2-3.1(3.6) mm wide, (2.0)2.1-2.9(3.2) times longer than wide, widest at $(0.2) 0.3-0.5(0.6)$ of the length. Petals (6.2)8.0-10.4(11.4) mm long and (3.0)3.5-6.0(6.8) mm wide, (1.3)1.4-2.4(2.7) times longer than wide, incision (0.8)1.4-3.1(3.6) $\mathrm{mm}$ deep, $(0.1) 0.1-0.3(0.4)$ of the total petal length. Capsules (5.3)6.1-11.4(12.1) × (3.1)3.7-4.4(5.0) mm, (1.4)1.5-2.7(3.2) times longer than wide, widest at (1.8) 1.9-4.0(5.4) $\mathrm{mm}$ distance from the basis, widest at (0.2)0.3-0.5(0.6) of the length, (0.8)0.9-1.8(1.9) times longer than the sepals. Seeds (0.4)0.8-1.6(2.2) $\mathrm{mm}$ long and (0.3)0.6-1.3(1.8) mm wide, 1.1-1.4(1.5) times 
longer than wide. Chromosome number unknown, but based on the relative genome size $2 n=36$ is expected.

Distribution: Endemic to the Albanian Alps (Alpet Shqiptare), where it is only known from three localities-Buni Jezercë, Maja Hekurave and Maja Kakisë.

Habitat: Northerly exposed humid screes with extended snow cover.

\section{Conservation status: Endangered (EN).}

\section{Key to the species of Cerastium dinaricum s.I}

Even if there is a strong overlap in character states between both species, it is possible to discriminate between them using a combination of characters given in the key. The most discriminating character, although not always distinct on herbarium specimens, is bold. Both species and their habitats are shown in Figs. 6 and 7.

1a. Densely caespitose perennial with ascending stems and (4)7-20(29) $\mathrm{mm}$ long internodes. Plants variable in indumentum, from completely glabrous to densely hairy. Leaves (2.3)2.8-5.2(6.1) times longer than wide. Sepals (2.8)5.0-6.9(7.2) mm long and (1.6)1.7-2.7(3.2) mm wide. Capsules (7.1)8.8-11.7(12.6) $\times(2.1) 2.9-4.8(5.5) \mathrm{mm}$, (1.7)2.0-3.4(3.9) times longer than wide. Seeds (0.1)1.4-1.9(2.0) long and (0.5)1.1-1.6(1.8) wide C. dinaricum

1b. Laxly caespitose perennial with decumbent stems and (10)17-27(30) $\mathrm{mm}$ long internodes. Plants with at least some glandular hairs. Leaves (1.7)2.0-4.0(5.6) times longer than wide. Sepals (5.3)5.4-7.9(8.0) $\mathrm{mm}$ long and (2.0)2.2-3.1(3.6) $\mathrm{mm}$ wide. Capsules (5.3)6.1-11.4(12.1) × (3.1)3.7-4.4 (5.0) $\mathrm{mm},(1.4) 1.5-2.7(3.2)$ times longer than wide. Seeds $(0.4) 0.8-1.6(2.2)$ long and (0.3)0.6-1.3(1.8) wide, (1.1)1.1-1.4(1.5) times longer than wide. C. hekuravense

Acknowledgements Open access funding provided by University of Innsbruck and Medical University of Innsbruck. This study was financed by the Austrian Exchange Service (OeAD) within the program WTZ and the Montenegrin Ministry of Science (Austria-Montenegro bilateral Project "ME04/2015-2016" to D. P. and B. F.). M. Niketić and Z. Barina provided locality data and gave valuable hints to relevant literature. We thank all collectors listed in Table 1 and Online Resource 1. The curator of the herbarium ZA provided herbarium material for morphometric analyses and Z. Barina sent us photos of type specimens. M. Gassner, D. Kutnjak and D. Pirkebner helped with laboratory work and M. Gassner with production of some figures. M. Magauer produced the iconography of both species. We are grateful to P. Daniel Schlorhaufer and his colleagues from the Botanical Gardens of the
University of Innsbruck for successfully cultivating our living collection of Cerastium. We thank two anonymous reviewers for valuable comments and suggestions.

\section{Compliance with ethical standards}

Conflict of interest The authors declare that they have no conflict of interest.

Open Access This article is distributed under the terms of the Creative Commons Attribution 4.0 International License (http://creativecommons.org/licenses/by/4.0/), which permits unrestricted use, distribution, and reproduction in any medium, provided you give appropriate credit to the original author(s) and the source, provide a link to the Creative Commons license, and indicate if changes were made.

\section{Information on Electronic Supplementary Material}

Online Resource 1. Voucher information about the outgroup taxa included in the AFLP analyses. Each population of each species has its specific population ID.

Online Resource 2. Character states of Cerastium dinaricum and $C$. hekuravense from morphometric analyses. For explanation of character abbreviations see Table 2 .

\section{References}

Arrigo N, Tuszynski JW, Ehrich D, Gerdes T, Alvarez N (2009) Evaluating the impact of scoring parameters on the structure of intra-specific genetic variation using RawGeno, an R package for automating AFLP scoring. BMC Bioinform 10:33. doi:10.1186/1471-2105-10-33

Ball PW (2011) Source of records for Albania in Flora Europaea, TRTE Herbarium. University of Toronto, Mississauga. Available at: http://www.erin.utoronto.ca/ trteherb/resources_assets/ Albania_V1.pdf

Barina Z, Pifkó D (2008) Additions and amendments to the flora of Albania. Willdenowia 38:455-464. doi:10.3372/wi.38.38206

Barina Z, Rakaj M, Pifkó D (2013) Contributions to the flora of Albania, 4. Willdenowia 43:165-184. doi:10.3372/wi.43.43119

Brysting AK, Oxelman B, Huber KT, Moulton V, Brochmann C (2007) Untangling complex histories of genome mergings in high polyploids. Syst Biol 56:467-476. doi:10.1080/10635150701424553

Brysting AK, Mathiesen C, Marcussen T (2011) Challenges in polyploid phylogenetic reconstruction: a case story from the arcticalpine Cerastium alpinum complex. Taxon 60:333-347

Demiri M (1983) Flora eskursioniste e Shqiperise. Shtepia Botuese e Shqiperise, Tirana

Dimopoulos P, Raus T, Bergmeier E, Constantinidis T, Iatrou G, Kokkini S, Strid A, Tzanoudakis D (2013) Vascular plants of Greece: an annotated checklist. Englera 31:1-372

Euro + Med (2006) Euro + Med PlantBase-the information resource for Euro-Mediterranean plant diversity. Available at: http://ww2.bgbm.org/EuroPlusMed. Accessed 15 Jan 2017

Frajman B, Oxelman B (2007) Reticulate phylogenetics and phytogeographical structure of Heliosperma (Sileneae, Caryophyllaceae) inferred from chloroplast and nuclear DNA sequences. Molec Phylogen Evol 43:140-155. doi:10.1016/j. ympev.2006.11.003

Frajman B, Eggens F, Oxelman B (2009) Hybrid origins and homoploid reticulate evolution within Heliosperma (Sileneae, 
Caryophyllaceae) - a multigene phylogenetic approach with relative dating. Syst Biol 58:328-345. doi:10.1093/sysbio/syp030

Frajman B, Pachschwöll C, Schönswetter P (2014) Contributions to the knowledge of the flora of the Dinarides (Balkan Peninsula). Phyton 54:27-46. doi:10.12905/0380.phython54(1)2014-0027

Frajman B, Rešetnik I, Weiss-Schneeweiss H, Ehrendorfer F, Schönswetter P (2015) Cytotype diversity and genome size variation in Knautia (Caprifoliaceae, Dipsacoideae). BMC Evol Biol 15:140. doi:10.1186/s12862-015-0425-y

Greilhuber J, Ebert I (1994) Genome size variation in Pisum sativum. Genome 37:646-655

Hayek A (1924) Zweiter Beitrag zur Kenntnis der Flora von Albanien. Denkschr Akad Wiss Wien Math-Naturwiss K1 99:101-223

Horvat I, Glavač V, Ellenberg H (1974) Vegetation südosteuropas. Gustav Fischer, Stuttgart

IUCN (2012) IUCN Red list categories and criteria: version 3.1, 2nd edition. IUCN, Gland. Available at: http://www.iucnredlist.org

Jalas A (1964) Cerastium L. In: Tutin TG, Heywood VH, Burges NA, Valentine DH, Walters SM, Webb DA (eds) Flora Europaea 4. Cambridge University Press, London, pp 136-143

Jalas A (1993) Cerastium L. In: Tutin TG, Burges NA, Chater OA, Edmondson JR, Heywood VH, Moore DM, Valentine DH, Walters SM, Webb DA (eds) Flora Europaea, 2nd edn. Cambridge University Press, London, pp 164-171

Jalas A, Suominen J (eds) (1983) Atlas Florae Europaeae, distribution of vascular plants 6. In: Committee for mapping the Flora of Europe. Societas Biologica Fennica Vanamo, Helsinki

Jávorka S (1921) Új adatok Albánia flórájához (Novitates florae Albanicae). Bot Közlem 19:17-29

Kryštufek B, Reed JM (2004) Pattern and processes in Balkan biodiversity - an overview. In: Griffits HI, Kryštufek B, Reed JM (eds) Balkan biodiversity: pattern and process in the European hotspot. Kluwer, Dordrecht, pp 203-217

Kutnjak D, Schönswetter P, Dullinger S, Kuttner M, Niketić M, Frajman B (2014) Escaping to the summits: phylogeography and predicted range dynamics of Cerastium dinaricum, an endangered high mountain plant endemic to the western Balkan Peninsula. Molec Phylogen Evol 78:365-374. doi:10.1016/j. ympev.2014.05.015

Markgraf F (1932) Pflanzengeographie von Albanien. E. Schweizerbart'sche Verlagsbuchhandlung, Stuttgart

Merxmüller H, Strid A (1977) A new species in the Cerastium alpinum group from Mt Olympus, Greece. Bot Notiser 130:469-472

Meyer FK (2011) Beiträge zur Flora von Albanien. Haussknechtia $15: 1-220$

Nei M, Li WH (1979) Mathematical model for studying genetic variation in terms of restriction endonucleases. Proc Natl Acad Sci USA 76:5269-5273

Niketić M (1999) Cerastium subsection of the genus Cerastium L. (Caryophyllaceae) on Balkan Peninsula. Annotated check-list. Glasn Prir Muz Beogradu Ser B 49-50:39-61

Niketić M (2007) Endemični predstavnici roda Cerastium L.u jugoistočnoj Evropi - Taksonomija, horologija i ekologija. PhD Thesis, Universitet u Beogradu, Beograd

Niketić M, Stevanović V (2007) A new species of Heliosperma (Caryophyllaceae) from Serbia and Montenegro. Bot J Linn Soc 154:5563. doi:10.1111/j.1095-8339.2007.00643.x

Niketić M, Siljak-Yakovlev S, Frajman B, Lazarević M, Stevanović B, Tomović G, Stevanović V (2013) Towards resolving the systematics of Cerastium subsect. Cerastium (Caryophyllaceae): a cytogenetic approach. Bot J Linn Soc 172:205-224. doi:10.1111/ boj. 12050

Paparisto K, Demiri M, Mitrushi I, Qosja XH (1988) Flora e Shqiperise, vol. 1. Akademia e Shkencave e RPS te Shqiperise, Qendra e Kerkimeve Biologjike, Tirana

Pils G (2016) Illustrated Flora of Albania. Eigenverlag G. Pils, St. Stefan

Qosja X, Paparisto K, Demiri M, Vangjeli J (1992) Flora e Shqiperise, vol. 2. Akademia e Shkencave e RPS te Shqiperise, Qendra e Kerkimeve Biologjike, Tirana

Qosja X, Paparisto K, Vangjeli J, Ruci B (1996) Flore e Shqiperise, vol. 3. Akademia e Shkencave e RPS te Shqiperise, Qendra e Kerkimeve Biologjike, Tirana

Rakaj M (2009) Floristic and chorological news from north Albania. Bot Serbica 33:177-183

Redžić S (2011) Phytogeographic and syntaxonomic diversity of high mountain vegetation in Dinaric Alps (Western Balkan, SE Europe). J Mountain Sci 8:767-786. doi:10.1007/ s11629-011-2047-1

Scheen AC, Brochmann C, Brysting AK, Elven R, Morris A, Soltis DE, Soltis PS, Albert V (2004) Northern hemisphere biogeography of Cerastium (Caryophyllaceae): insights from phylogenetic analysis of noncoding plastid nucleotide sequences. Amer J Bot 91:943-952

Schönswetter P, Schneeweiss GM (2009) Androsace komovensis sp. nov., a long mistaken local endemic from the southern Balkan Peninsula with biogeographic links to the Eastern Alps. Taxon 58:544-549

StatSoft (1996) STATISTICA (data analysis software system), version 5.1. Tulsa: StatSoft Inc. www.statsoft.com

Stevanović V, Kit T, Petrova A (2007) Mapping the endemic flora of the Balkans-a progress report. Bocconea 21:131-137

Surina B, Rakić T, Stefanović S, Stevanović V, Lakušić D (2009) One new species of the genus Edraianthus, and a change in taxonomic status for Edraianthus serpyllifolius f. pilosulus (Campanulaceae) from the Balkan Peninsula. Syst Bot 34:602-608. doi:10.1600/036364409789271236

Surina B, Pfanzelt S, Einzmann HJR, Albach DC (2014) Bridging the Alps and the Middle East: evolution, phylogeny and systematics of the genus Wulfenia (Plantaginaceae). Taxon 63:843-858

R Development Core Team (2012) R: A language and environment for statistical computing. R Foundation for Statistical Computing, Vienna, Austria. Available at: www.R-project.org

Tel-Zur N, Abbo S, Myslabodski D, Mizrahi Y (1999) Modified CTAB procedure for DNA isolation from epiphytic cacti of genera Hylocereus and Selenicereus (Cactaceae). Pl Molec Biol Rep 17:249-254

van de Peer Y, De Wachter R (1997) Construction of evolutionary distance trees with TREECON for Windows: accounting for variation in nucleotide substitution rate among sites. CABIOS 13:227-230. doi:10.1093/bioinformatics/13.3.227

Vangjeli J (2003) Udhëheqës fushor i florës së Sqipërisë. Shkenca, Tiranë

Vangjeli J, Ruci B, Mullaj A, Paparisto K, Qosja XH (2000) Flora e Shqiperise, vol. 4. Akademia e Shkencave e Republikes se Shqiperise, Instituti i Kerkimeve Biologjike, Tirane 